\title{
The Role of Labelling of Chemical Substances Contents in Recycling Promotion - Japanese Case
}

\section{Mizue Kama* and Toshikazu Shiratori}

Graduate School of Environmental Studies, Tohoku University, Japan

\begin{abstract}
In this study, we investigate the effect of new legislative requirements on industrial product development. We use the case of Restriction of Hazardous Substances (RoHS) Directive and the development of halogen-free (HF) printed circuit board (PCB) in an attempt to answer the following questions: (1) What impacts can environmental regulations - such as RoHS Directive - have on the manufacturing industry? (2) How have the manufacturers - especially those outside the European Union (EU) -responded to the RoHS Directive? (3) How has the manufacturing of HF products progressed in the wake of the directive? In order to investigate these, we focused the issue of halogen in the thermosetting resin of PCB of mobile phone. We illustrated their time trend of HF PCB labelling method and actual $\mathrm{Br}$ existence among many manufacturers in each milestone of the regulations. Finally, almost manufacturer complied with RoHS Directive, but each starting time was different. The results of this research are the first example to illustrate this fact in the history of the electronic industry.
\end{abstract}

Keywords: E-waste; RoHS directive; WEEE directive; Printed circuit board; Halogen free; Supply chain; Labelling

\section{Introduction}

\section{Background}

Today, the increasing amount of waste is a world issue. For example, waste amounts in the EU were recorded at 2,514 million tons in 2012. Along the same lines, electrical waste (e-waste) is one of the fastest growing types of waste. E-waste involves issues such as short product lifespan and overall complexity. Regarding increasing amounts of e-waste, the European Commission (EC) stated: the

"The problems to which waste gives rise are both specific and relatively complex: waste is not only a potential source of pollution but can also constitute "secondary" natural resources.... The choice of priorities will have direct economic and environmental consequences". This means the EC intends to construct a strategy to decrease the amount of waste and utilize waste as a secondary natural resource [1].

However, during this waste prevention and utilization experiment, as existing research has shown [2], the EU realized the necessity for hazardous substances management to ensure the quality of secondary natural resources. On this issue, the EU presented related concepts in their 5th Environmental Action Programme. The concepts involved 'preventing waste' and 'encouraging maximum recycling' of hazardous waste. These concepts are applicable during multiple phases such as throughout the complete life cycle of the product and they can affect environmental policy integration regarding hazardous substance management [3]. E-waste management policy integration can be found in both the Restriction of the use of Hazardous Substances (RoHS) Directive and the Waste Electrical and Electronic Equipment (WEEE) Directive $[4,5]$.

The WEEE Directive [5] requires EU Member States to construct a separate e-waste collection system. The RoHS Directive [4] requires EU Member States to ensure that electrical and electronic equipment (EEE) does not contain certain hazardous substances. These directives generally address Member States; however, the RoHS Directive actually addresses manufacturers world-wide. They also must restrict the usage of certain hazardous substances specified in the directive and must update their EEE. Therefore, nowadays, new EEE must have a specific label attached (Figure 1) for a self-declaration of compliance with the new RoHS Directive. Before, manufacturers were required to attach these labels, as shown in Figure 1, they attached another specific label attached (Figure 2) which are provided by manufacturers. On the one hand, this labelling declares 'this is non-hazardous and environmentally sound EEE' [7]. On the other hand, users cannot be certain that EEE has been updated. To measure the effects of the directive, the changes to EEE as set forth by the RoHS Directive must be investigated. To this end, in this study, we investigate the effects of the new legislative requirements on industrial product development.

\section{Outline of RoHS Directives}

The RoHS Directive was adopted on 13 February 2003 and enacted on 1 July 2006. This directive requires the following in Article 4(1): 'Member States shall ensure that, from 1 July 2006, new electrical and electronic equipment put on the market does not contain lead, mercury, cadmium, hexavalent chromium, polybrominated biphenyls (PBB) or polybrominated diphenyl ethers (PBDE)'. In 2005, the RoHS Directive amended the maximum values for these substances as illustrated in Table 1.

Therefore, manufacturers amended their production or procurement standards and/or processes to eliminate the six hazardous substances from their products to comply with RoHS requirements. However, their efforts were not publicized. This is why we decided to conduct a study involving EEE dismantling and X-ray analysis.

We use the case of the RoHS Directive and the development

*Corresponding author: Kama M, Graduate School of Environmental Studies, Tohoku University, Japan 6-6-20, Aoba, Aoba-ku, Sendai, 980-8579, Japan; Tel: +81-22-795-7420; E-mail: will.tsukuyomiszuki@gmail.com

Received October 04, 2016; Accepted October 17, 2016; Published October 24 2016

Citation: Kama M, Shiratori T (2016) The Role of Labelling of Chemical Substances Contents in Recycling Promotion - Japanese Case. Int J Waste Resour 6: 251. doi: 10.4172/2252-5211.1000251

Copyright: $\odot 2016$ Kama M, et al. This is an open-access article distributed under the terms of the Creative Commons Attribution License, which permits unrestricted use, distribution, and reproduction in any medium, provided the original author and source are credited. 
Citation: Kama M, Shiratori T (2016) The Role of Labelling of Chemical Substances Contents in Recycling Promotion - Japanese Case. Int J Waste Resour 6: 251. doi: 10.4172/2252-5211.1000251

Page 2 of 3

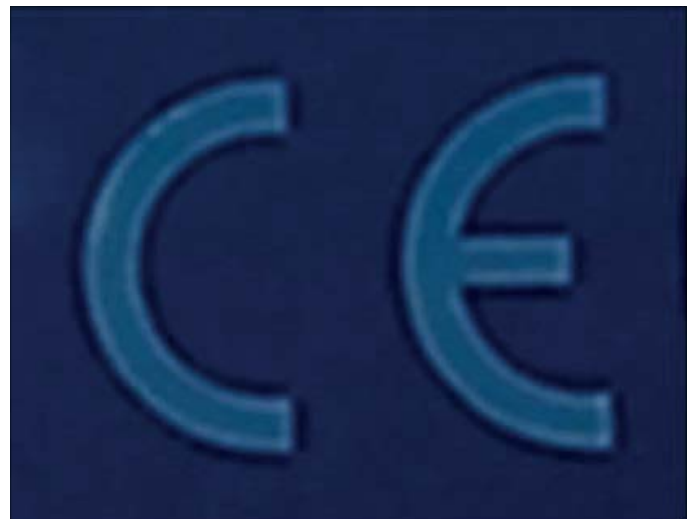

Figure 1: Examples CE marking required in new RoHS Directive.
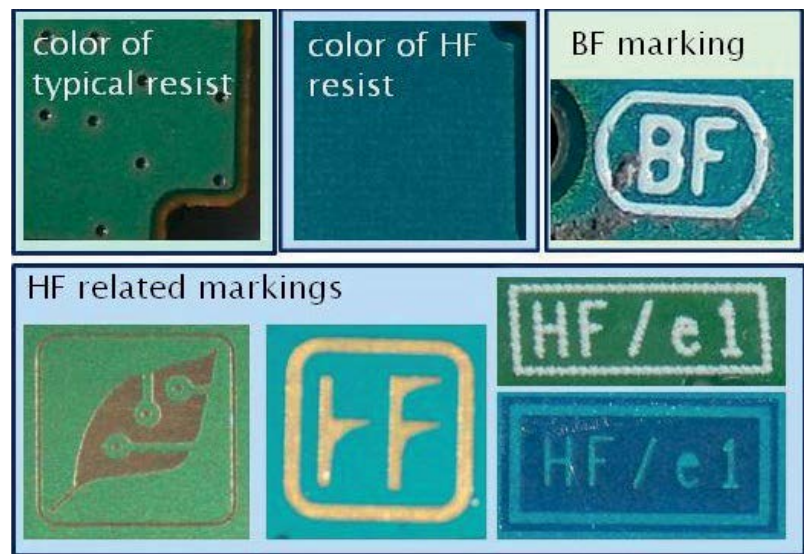

Figure 2: Examples of HF related markings provided by manufacturers RoHS1.

\begin{tabular}{|c|c|}
\hline Restricted substances & Maximum tolerated value \\
\hline Lead & $0.1 \%$ \\
\hline Mercury & $0.1 \%$ \\
\hline Cadmium & $0.01 \%$ \\
\hline Hexavalent chromium & $0.1 \%$ \\
\hline Polybrominated biphenyls (PBB) & $0.1 \%$ \\
\hline Polybrominated biphenyl ethers (PBDE) & $0.1 \%$ \\
\hline
\end{tabular}

Table 1: Restricted substance by RoHS1.

of halogen-free (HF) printed circuit boards (PCBs) in an attempt to answer the following questions:

1. What impacts can environmental regulations such as the RoHS Directive have on the manufacturing industry?

2. How have manufacturers, especially those outside of the EU, responded to the RoHS Directive?

3. How has the manufacturing of HF products progressed in the wake of the RoHS Directive?

\section{Materials and Methods}

We studied the historical changes in the development of PCBs in mobile phones manufactured between 1997 and 2008, during which time, the RoHS Directive developed from conception to implementation. A total of 260 mobile phone sets from 17 different manufacturers were studied. They covered almost whole manufacturers such as Casio, Ericsson, Hitachi, HTC, Huawei, Kyocera, LG, NEC, Nokia, Panasonic, Samsung, Sharp, Sony, and Toshiba, etc... Mobile phones have evolved rapidly in a short period and the information for each production year was readily available, making it a good case product for our study.

First, all sampled mobile phone sets were dismantled and the PCBs were separated. The PCBs were then checked for HF-related marks (Figure 2). Further, cross section PCB specimens were prepared in order to prevent the interference of $\mathrm{Cu}$ in the PCB (upper side of Figure 3). Finally, the prepared samples were analysed qualitatively for Br using an X-ray Fluorescence Analytical Microscope (Horiba XGT-7000V). Final photo images were shown in the lower side of Figure 3.

\section{Results}

Different patterns of transition to HF PCBs (Br was unused and neglected) were observed among the manufacturers (Figure 4). The key findings can be summarized as follows:

1. The transition period varied by manufacturer, this can be classified into eight groups.

2. Some manufacturers began a trial production for HF PCBs even before the introduction of the RoHS Directive.

3. Most manufacturers complied when the directive came into effect in July 2006.

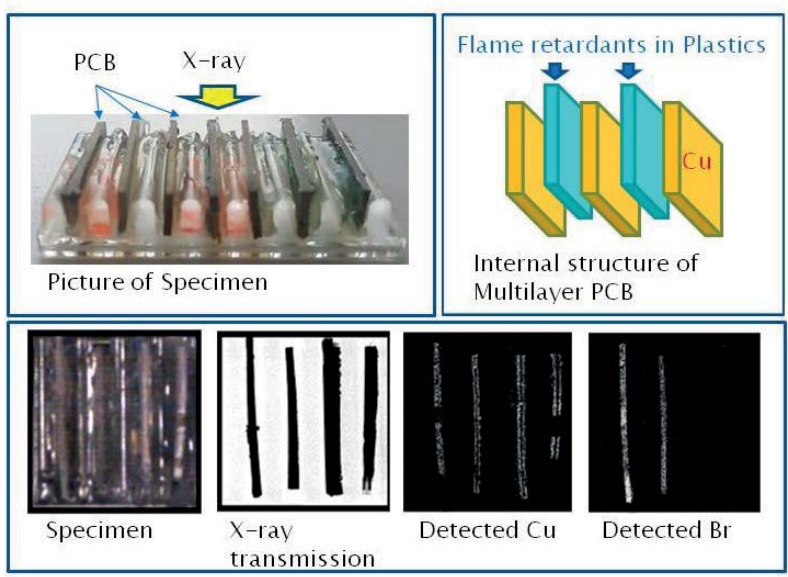

Figure 3: Specimen and the photo image by XGT.

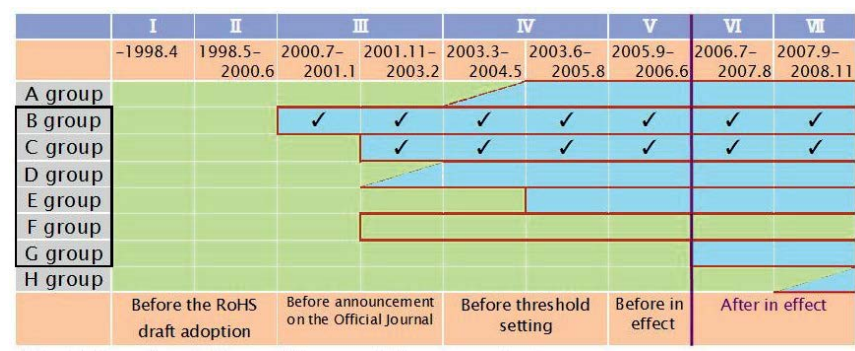

Figure 4: Result of dismantling and $X$-ray analysis.

* within BLACK frame (Group B-G): Japanese manufacturers

** within the RED frame : Comply with RoHS requirement

GREEN area is color of typical resist and BLUE area is color of HF resist on $\mathrm{PCB}$, as shown in Figure1

$\checkmark$ : HF related marking as shown in Figure 2 
4. While the majority of the HF PCBs had some visual effects (different colour or an HF-related mark), some manufactures did not adapt any visual effects.

\section{Discussion}

The RoHS Directive covers six hazardous substances, of which it was said to be quite difficult to develop alternatives to $\mathrm{Pb}$ and $\mathrm{Br}$. However, lead-free solders are now used by the entire industry [8] and the issue of halogen in the thermosetting resin of PCBs was addressed by each producer individually [9] as invisible information. This is why we decided to focus on HF PCBs.

There are two main reasons for the early adaptation of the RoHS Directive in the PCB manufacturing industry. First, the industry had already aimed to abolish the use of halogen, as it was discussed in the first draft of the RoHS Directive. Second, the qualitative analysis of the compounds prohibited by the RoHS Directive, polybrominated biphenyl (PBB) and polybrominated diphenyl ethers (PBDE), were cost intensive. Achieving halogen-free status (regardless of the types of compounds) meant avoiding a costly analysis and reducing inspection costs.

You could find the definition referred in amended RoHS Directive [7] (hereinafter RoHS2.0) definition in article 3 as following; 'homogeneous material' means one material of uniform composition throughout or a material, consisting of a combination of materials, that cannot be disjointed or separated into different materials by mechanical actions such as unscrewing, cutting, crushing, grinding and abrasive processes'.

This article is taken in context from RoHS Directive FAQ, not means one part needs only one analysis [7]. For example, if one part is composed by 10 materials, it needs the analysed data of 10 materials for proving the compliance with RoHS Directive requirement. As seen from the above, definition of 'homogeneous material' recognize in directive from RoHS 2.0. Therefore, manufacturers had no way of telling proved of compliance in 2003. Since then, they developed and utilize the portable X-ray analytical equipment or elemental mapping analysis instruments such as XRF micro scope and establish their own supply chain management [10].

In addition, the RoHS Directive resulted in the advancement of the supply chain management system not only for parts and materials but also for final products. The manufacturers, especially those from Japan, attained thoroughly regulated management systems due to the following reasons:

1. There was a risk of losing the European market if they could not comply with the regulations.

2. Japanese manufacturers had the required technical skills to comply with the standards.

3. Compliance would give them an advantage over other manufacturers and therefore, they were willing to invest in its development.

4. In order to avoid the risk of non-compliance, the procured materials were also included in the analysis.

\section{Conclusion}

Although regulations are often considered a burden for many manufacturers, the example of the RoHS Directive shows that when the industry is involved in the process with the appropriate incentives, it is possible to produce good results in a short period of time. The results of this research are the first example to illustrate this fact in the history of the electronic industry.

\section{Acknowledgement}

We thank Dr. Kano of Eco-recycle Co., Ltd., Japan and Stena Metall AB Sweden for assistance with the test sample collection.

\section{References}

1. Commission of the European Community (1989) Communication from the commission to the council and to parliament.

2. Dette B, Julich R, Buchert M, Bukhave M, Dopfer J, et al. (1999) Waste prevention and minimisation. Öko-Institut eV.

3. European Commission (1993) Towards sustainability A European Community programme of policy and action in relation to the environment and sustainable development.

4. European Parliament and of the Council (2003) Directive 2002/95/EC on the restriction of the use of certain hazardous substances in electrical and electronic equipment.

5. European Parliament and of the Council (2003) Directive 2002/96/EC of the European Parliament and of the Council of 27 January 2003 on Waste Electrical and Electronic Equipment (weee)

6. European Parliament and of the Council (2011) Directive 2011/65/EU of the European Parliament and of the Council of 8 June 2011 on the restriction of the use of certain hazardous substances in electrical and electronic equipment.

7. European Commission Directorate-General Environment (2006) Frequently Asked Questions on Directive 2002/95/EC on the Restriction of the Use of certain Hazardous Substances in Electrical and Electronic Equipment (RoHS) and Directive 2002/96/EC on Waste Electrical and electronic Equipment (WEEE).

8. Japan Electronics and Information Technology Industries Association (2005) "JEITA Namari free-ka kansui kinkyuu teigen houkokusho,". JEITA, Tokyo, Japan.

9. Yamaguchi M, Shigyo H, Yamamoto $Y$, Sudo S, Ito S (1997) Non halogen/ antimony flame retardant system for high end IC package. In: Electronic Components and Technology Conference, 1997. Proceedings., 47th (pp. 12481253). IEEE.

10. Hitachi co Itd (2016) Green Procurement Guidelines Ver.8.3. 